Bangladesh J. Plant Taxon. 16(1): 21-28, 2009 (June)

(C) 2009 Bangladesh Association of Plant Taxonomists

\title{
POLLEN MORPHOLOGY OF AGROPYRON GAERTNER IN TURKEY
}

\author{
Hülya Özler ${ }^{1}$, Evren $\mathrm{CABI}^{2}$, Ebru $\mathrm{Us}^{3}$, Musa DoĞan and Sevil Pehlivan ${ }^{3}$ \\ Department of Biology, Faculty of Science, Middle East Technical University, \\ Ankara, Turkey.
}

Keywords: Agropyron; Pollen morphology; SEM; Turkey.

\begin{abstract}
Pollen morphology of Agropyron cristatum (L.) Gaertner. s.s. (subsp. incanum (Nábělek) Melderis and subsp. pectinatum (M. Bieb.) Tzvelev, latter including var. pectinatum and var. imbricatum (Roemer \& Schultes) G. Beck) in Turkey has been studied by using light microscope and scanning electron microscope. The above-mentioned taxa are homogenous in both aperture type and exine ornamentation. Pollen grains are monoporate (rarely diporate in the case of var. imbricatum) having scabrate grouped exine surface. The scabra density and the height of scabrae as well as other morphological parameters such as annulus and operculum diameter are peculiar features for differentiation of taxa. Two different phenograms were created with the UPGMA (Unweighted Pair Group Method with Arithmetic mean) clustering technique using quantitative measurements of the pollen grains.
\end{abstract}

\section{Introduction}

The taxonomy of Agropyron Gaertner (Poaceae) was studied in different ways by various researchers. In a broad sense, it was once thought to be one of the largest genera encompassing more than 100 species in the tribe Triticeae Dumort (Dewey, 1983). Nevski (1934) treated Agropyron as a small genus consisting only of the species with keeled glumes. The remaining taxa were placed in Elytrigia Desv, Roegneria C. Koch and Elymus L. Agropyon has been restricted to the species with $\mathrm{P}$ genome composed of three ploidy levels $(2 \mathrm{x}=14,4 \mathrm{x}=28,6 \mathrm{x}=42)$ (Dewey and Asay, 1975; Melderis, 1978; Dewey, 1983; Assadi, 1995; Jensen et al., 2006). This narrow concept of Agropyron has been accepted by many authorities. The major Eurasian floras have followed the generic concept of Nevski (Tzvelev, 1976; Melderis et al., 1980; Melderis, 1985).

Much confusion prevailed regarding the number of species included in this genus. Dewey and Pendse (1967) considered all the crested wheatgrasses, regardless of ploidy level, as a single breeding population. Tzvelev (1976) recognized 10 species in Agropyron and nine subspecies in Agropyron cristatum (L.) Gaertner.

Agropyron cristatum is represented by two subspecies in Turkey, namely subsp. incanum (Nábělek) Melderis distributed in East Anatolia and subsp. pectinatum (M. Bieb.) Tzvelev distributed throughout Turkey. Morphologically, subsp. incanum is

\footnotetext{
${ }^{1}$ The Ministry of Environment and Forest, Forest Tree Seeds and Tree Breeding Research Directorate, P.O. Box 11, 06560 Gazi, Ankara, Turkey.

${ }^{2}$ Corresponding author. E-mail: ecabi@metu.edu.tr, ecabi2004@yahoo.com

${ }^{3}$ Department of Biology, Faculty of Science, Gazi University, Ankara, Turkey.
} 
distinctly different by having spikes with closely pressed together spikelets and densely pilose lemmas contrary to subsp. pectinatum. Subspecies pectinatum includes two varieties viz. var. imbricatum (Roemer \& Schultes) G. Beck which has pilose spikelets and var. pectinatum with glabrous spikelets (Melderis, 1985).

There have been some studies regarding pollen morphology of members of tribe Triticeae, especially the economically important genera such as Triticum L., Secale L., and Hordeum L. (Faegri and Iversen, 1975; Köhler and Lange, 1979; Kruse, 1980; Panajiotidis et al., 2000; Kalinowski et al., 2005), but rarely on taxa of Agropyron (Smith, 2000).

The aim of this paper is to describe the palynological features of three taxa of the genus Agropyron available in Turkey and also to contribute to their taxonomy showing some differences between them regarding their exine sculptures.

\section{Materials and Methods}

Pollen samples from each of the three studied taxa were obtained from herbarium specimens listed in Table 1. The identifications of the specimens were made according to the Agropyron accounts given in Flora of Turkey (Melderis, 1985). For the light microscope study, the pollen grains were prepared following the Wodehouse (1935) and Erdtman (1952) methods. Morphological features of 30 pollen grains were measured using Leica DM 1000 and their microphotographs were taken by the Leica DFC280 camera attachment. The measurements included the following parameters: long axis of spheroidal pollen grains (A), short axis of spheroidal pollen grains (B), long axis of ellipsoidal pore, short axis of ellipsoidal pore, exine thickness, annulus diameter, A/B ratio indicating shape of a spheroidal pollen grain, operculum diameter, thickest part of intine, and intine thickness.

Table 1. Investigated taxa with their site of collections.

\begin{tabular}{|c|c|c|c|c|}
\hline$\#$ & Coll. No. & Taxon & Locality & Altitude \\
\hline 1 & $\begin{array}{l}\text { E. Cabi } \\
2545\end{array}$ & $\begin{array}{l}\text { Agropyron cristatum (L.) Gaertner } \\
\text { subsp. incanum (Nábělek) Melderis }\end{array}$ & $\begin{array}{l}\text { A8 Erzurum: Aşkale to Bayburt, Kop } \\
\text { Mount, Kop pass, calcerous slopes } \\
\left(40^{\circ} 01^{\prime} 38^{\prime \prime N}, 40^{\circ} 31^{\prime} 20^{\prime \prime} \mathrm{E}\right)\end{array}$ & $2401 \mathrm{~m}$ \\
\hline 2 & $\begin{array}{l}\text { E. Cabi } \\
2258\end{array}$ & $\begin{array}{l}\text { Agropyron cristatum subsp. pectinatum } \\
\text { (M. Bieb.) Tzvelev var. imbricatum } \\
\text { (Roemer \& Schultes) G. Beck }\end{array}$ & $\begin{array}{l}\text { A9 Kars: Kuyucak village, Kuyucak } \\
\text { Lake environments, dry pastures } \\
\left(40^{\circ} 43^{\prime} 41^{\prime \prime N}, 43^{\circ} 25^{\prime} 30^{\prime \prime E}\right)\end{array}$ & $1642 \mathrm{~m}$ \\
\hline 3 & $\begin{array}{l}\text { E. Cabi } \\
2244\end{array}$ & $\begin{array}{l}\text { Agropyron cristatum subsp. pectinatum } \\
\text { var. pectinatum }\end{array}$ & $\begin{array}{l}\text { B6 Sivas: Sivas Cumhuriyet } \\
\text { University Campus, roadside and } \\
\text { under forest }\left(39^{\circ} 42^{\prime} 28^{\prime \prime} \mathrm{N} \text {, }\right. \\
\left.37^{\circ} 01^{\prime} 10^{\prime \prime} \mathrm{E}\right)\end{array}$ & $1275 \mathrm{~m}$ \\
\hline
\end{tabular}

Using the average values of pollen measurements, phenograms of the investigated taxa were produced for fresh (W, Wodehouse) and acetolysed (E, Erdtman) pollen grains 
based on the Gower General Similarity Coefficient. Gower's (1971) coefficient was chosen to generate a distance matrix. This distance matrix was used for cluster analysis with the help of UPGMA algorithm (Sneath and Sokal, 1973). Correlation values were obtained using SPSS version 11.0 (SPSS, 1999).

For scanning electron microscope (SEM) studies, pollen grains were put on stubs, sputter coated with gold and examined under Jeol JSM-6060LV SEM at the central laboratory of Middle East Technical University. The terminologies for pollen morphology were used in accordance with Wodehouse (1935), Faegri and Iversen (1989), and Chaturvedi et al. (1998).

\section{Results and Discussion}

The means and standard deviations of the measured pollen parameters of taxa are given in Table 2. All investigated taxa had heteropolar, monoporate (rarely diporate in the case of var. imbricatum) and spheroidal pollen grains. The pore was surrounded by an annulus and it was partly covered by an operculum. Pollen grains of Gramineae were classified as annulate or nonannulate and operculate or nonoperculate by Perveen (2000, 2006), Chaturvedi et al. (1998) and Salgado-Labouriau and Rinaldi (1990). They also rarely observed diporate pollen grains. In this study, we observed that all taxa were annulate and operculate (Figs 1-3).

The exine ornamentation types in Gramineae were defined as insular, granulose, spinulose, verrucose, brevicerebro ornate (Chaturvedi et al., 1994, 1998; Liu et al., 2004). Erdtman (1969), Moore and Webb (1978) and Moore et al. (1991) used the term scabrate for exine sculpture covered with small $(<1 \mu \mathrm{m})$ elements, equivalent to granulate exine ornamentations. According to our SEM investigations, exine sculpture is scabrate in all examined taxa (Figs 1-3).

Köhler and Lange (1979) proposed that the number of spinules may be used for identification. In present study, we found that the investigated taxa could be differentiated based on exine parameters such as the number and height of scabrae and the distance between the scabrae. In all investigated taxa, 2 to 4 scabrae were observed in each group. The distance between scabrae was greater in Agropyron cristatum subsp. incanum than other two taxa. Based on scabra number and height, var. pectinatum can be differentiated from other two taxa (Figs 1-3). Scabrae density was $19-20$ no./ $\mu \mathrm{m}^{2}$ in subsp. pectinatum var. pectinatum, $8-9$ no. $/ \mu \mathrm{m}^{2}$ in subsp. pectinatum var. imbricatum, and $5-7$ no. $/ \mu \mathrm{m}^{2}$ in subsp. incanum. The highest scabra was $0.29 \mu \mathrm{m}$ in subsp. pectinatum var. pectinatum, $0.18 \mu \mathrm{m}$ in subsp. pectinatum var. imbricatum, and $0.17 \mu \mathrm{m}$ in subsp. incanum. The scabrae were wider in subsp. incanum $(0.32 \mu \mathrm{m})$ than in subsp. pectinatum var. imbricatum $(0.26 \mu \mathrm{m})$ and in var. pectinatum $(0.21 \mu \mathrm{m})$.

Exine was thicker in subsp. pectinatum var. imbricatum and subsp. incanum than subsp. pectinatum var. pectinatum (Table 2). Typical measurements for exine thickness 


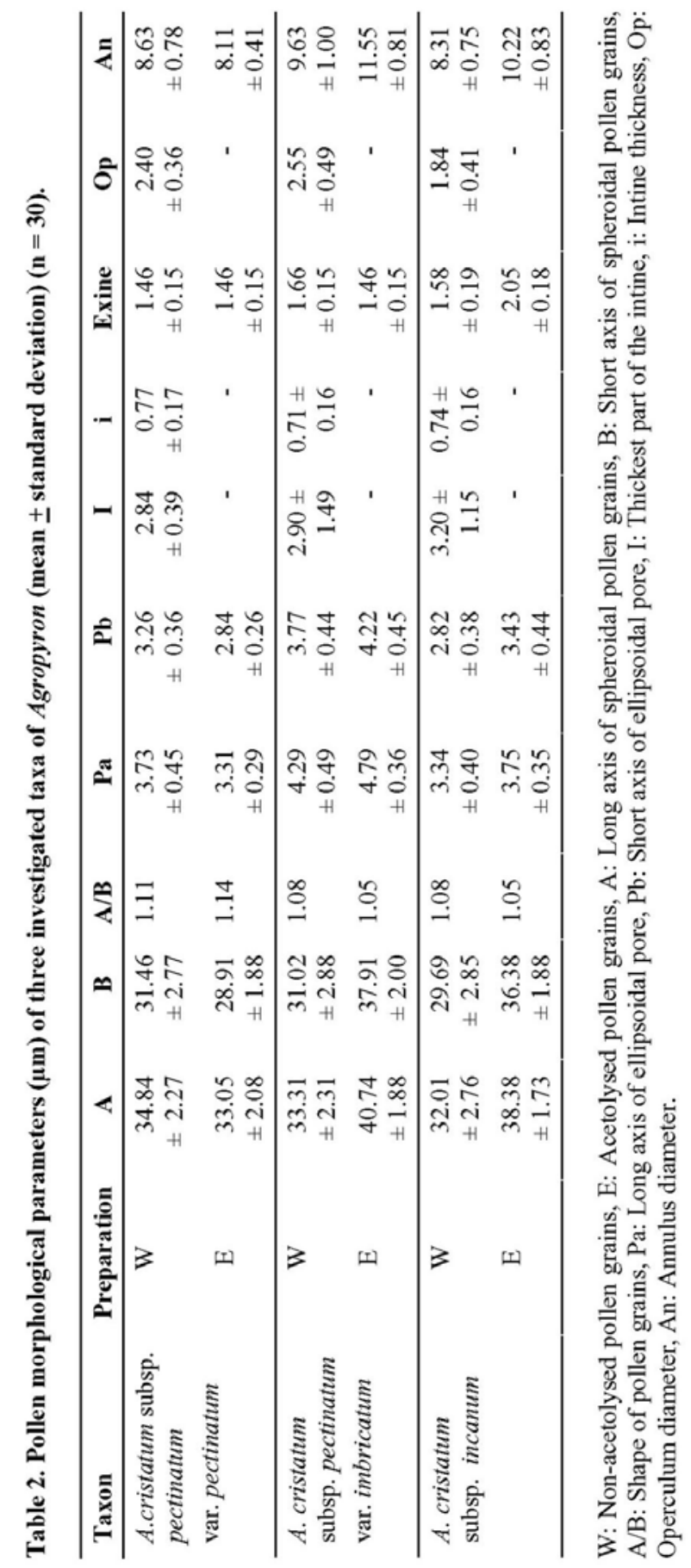


of Gramineae are (0.5-)0.85-1.10(-1.53) $\mu \mathrm{m}(\mathrm{W})$ and 1.02-1.61 $\mu \mathrm{m}$ (E) (Erdtman, 1943; Lewis et al., 1983; Salgado-Labourian and Rinaldi, 1990; Liu et al., 2004; Pehlivan et al., 2004).
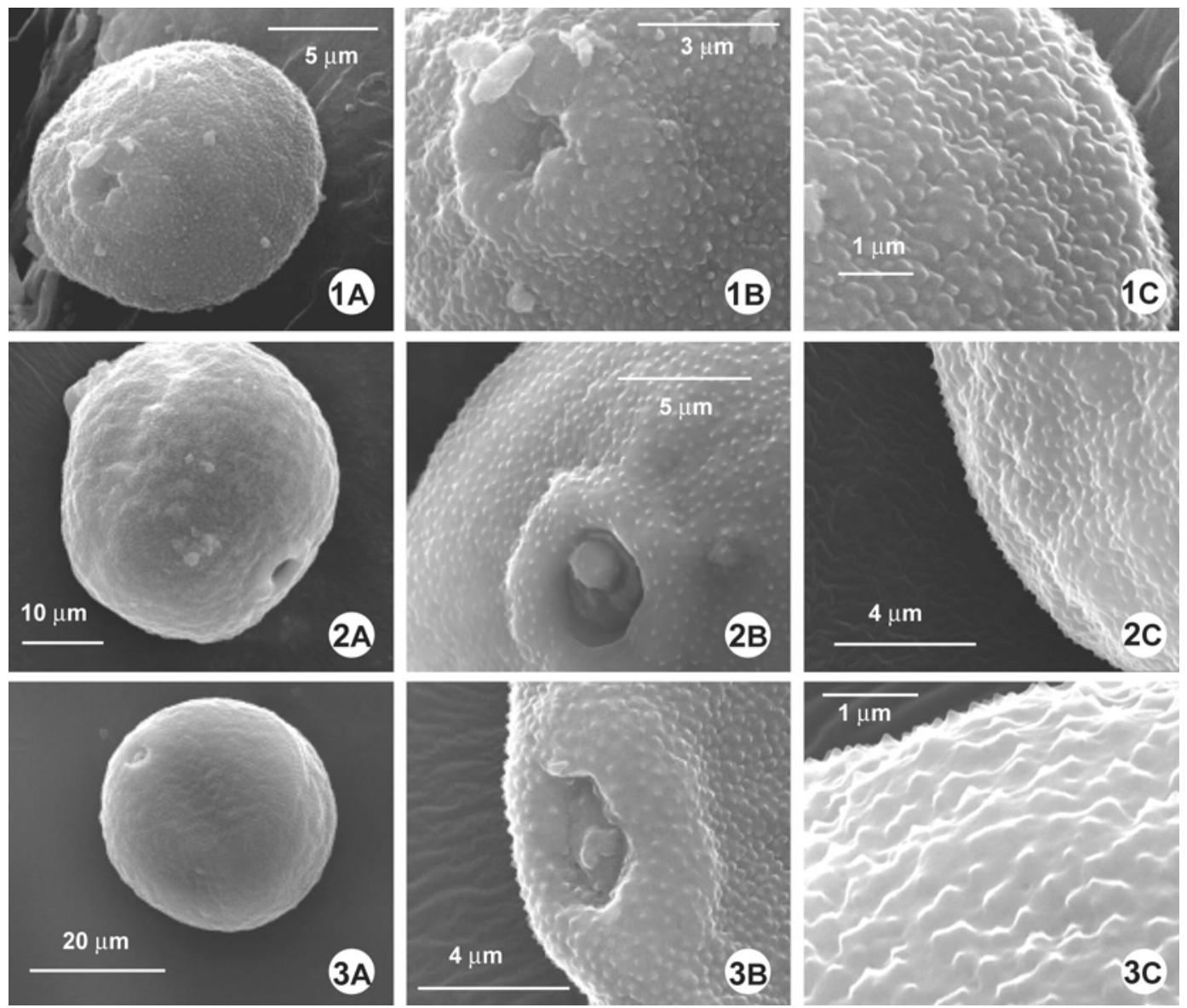

Figs 1-3. 1. Agropyron cristatum subsp. pectinatum var. pectinatum. A. Slightly oblique polar view with distinct annulus; B. Aperture view with operculum; C. Scabrate grouped exine surface. 2. A. cristatum subsp. pectinatum var. imbricatum. A. Pollen grain in equatorial view; B. Aperture view with distinct annulus; C. Scabrate with grouped exine surface. 3. A. cristatum subsp. incanum. A. Pollen grain in equatorial view; B. Aperture view with distinct annulus; C. Scabrate with grouped exine surface.

Liu et al. (2004) found a positive correlation between pollen and aperture size and between aperture and annulus diameter. In our study, both acetolysed (E) and fresh pollen (W) measurements also showed that there are strong positive correlations between the long axis of pollen grain and pore, and short axis of pollen grain and pore (Table 3). 
Table 3. Correlation coefficient for different pollen morphological parameters at $\boldsymbol{P}<\mathbf{0 . 0 0 1}$.

\begin{tabular}{|c|c|c|c|c|c|c|}
\hline & \multicolumn{3}{|c|}{ Wodehouse (W) } & \multicolumn{3}{|c|}{ Erdtman (E) } \\
\hline & $\mathrm{Pb}$ & A & B & $\mathrm{Pb}$ & A & B \\
\hline $\mathrm{Pa}$ & 0.999 & 0.365 & & 0.989 & 0.901 & \\
\hline $\mathrm{Pb}$ & & & 0.687 & & & 0.875 \\
\hline A & & & 0.946 & & & 0.946 \\
\hline
\end{tabular}

W: Non-acetolysed pollen grains, E: Acetolysed pollen grains, A: Long axis of spheroidal pollen grains, B: Short axis of spheroidal pollen grains, $\mathrm{Pa}$ : Long axis of ellipsoidal pore, $\mathrm{Pb}$ : Short axis of ellipsoidal pore.

Differences between measurements of fresh and acetolysed pollen grains resulted in the formation of different clusters. Although the two subspecies differentiated distinctively and the varieties of subsp. pectinatum formed a tight cluster with respect to their quantitative pollen data obtained from fresh pollen grains, var. pectinatum formed a different cluster due to their acetolysed pollen grains (Fig. 4). The phenogram obtained from measurements of fresh pollen grains is much more suitable for separating the taxa regarding their morphological pollen features in the genus Agropyron. Although acetolysed pollen grains give excellent topographic information, but due to the very process of acetolysis they get modified, thus do not represent actual size.

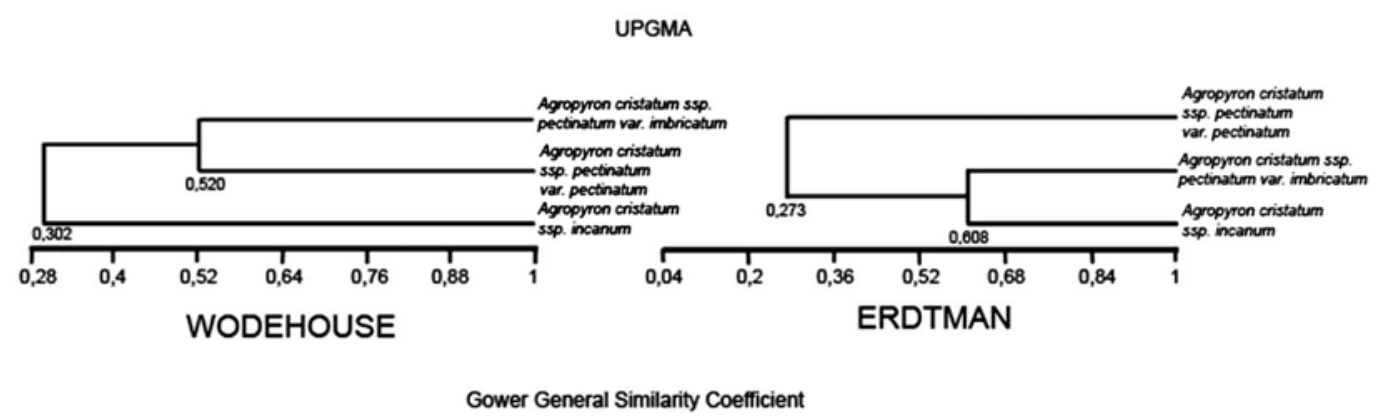

Fig. 4. UPGMA phenograms of the investigated taxa based on Gower General Similarity Coefficient.

The results indicate that the genus Agropyron has stenopalynous pollen grains, thus the value of pollen characters for taxonomic applications is limited. Faegri and Iversen (1975), Andersen (1978), and Perveen (2006) also indicated similar uniformity in pollen grains of Poaceae. The application of cluster analysis showed the possibility of using quantitative data based on fresh pollen grains for differentiating the taxa. The density of scabrae and the distance between the scabrae can be used as the most functional differentiating characters. 


\section{Acknowledgements}

The authors would like to thank to Central Laboratory personnel of Middle East Technical University for their assistance in coating the pollen samples and taking their photographs during the SEM studies and to the Scientific and Technical Research Council of Turkey (TUBITAK-TBAG-105 T 171) for their financial assistance. The authors would like to thank Mr. Umut Toprak for his valuable efforts to edit the manuscript.

\section{References}

Andersen, S.Th. 1978. Identification of wild grass and cereal pollen.-Danm. Geol. Unders., Arborg, pp. 69-92.

Assadi, M. 1995. Meiotic configuration and chromosome number in some Iranian species of Elymus. Botanical Journal of the Linnean Society 117:159-168.

Chaturvedi, M., Datta, K. and Nair, P.K.K. 1998. Pollen morphology of Oryza, Poaceae. Grana 37: 79-86.

Chaturvedi, M., Yunus, D. and Data, K. 1994. Pollen morphology of Sorghum Moench-sections Eu-sorghum and Para-sorghum. Grana 33: 117-123.

Dewey, D.R. 1983. Historical and current taxonomic perspectives of Agropyron, Elymus and related genera. Crop Sci. 23: 637-642.

Dewey, D.R. and Asay, K.H. 1975. The crested wheatgrasses of Iran. Crop Sci. 15: 844-849.

Dewey, D.R. and Pendse, P.C. 1967. Cytogenetics of crested wheatgrass Triploids. Crop Sci. 7: 345-349.

Erdtman, G. (ed.) 1943. An Introduction to Pollen Analysis. Chronica Botanica, Waltham, MA, pp. 1-239.

Erdtman, G. (ed.) 1952. Pollen Morphology and Plant Taxonomy, Angiosperms. The Chronica Botanica Co., Walthan, Mass., Almquist Wiksell, Stockholm, Sweden, pp. 1-539.

Erdtman, G. (ed.) 1969. Handbook of Palynology. An introduction to the study of pollen grains and spores. Munskgaard, Copenhagen, pp. 1-486.

Faegri, K. and Iversen, J. 1975. Textbook of Pollen Analysis. $3^{\text {rd }}$ Edition. Munksgaard, Copenhagen, pp. 1295.

Faegri, K. and Iversen, J. (eds) 1989. Textbook of Pollen Analysis. John Wiley and Sons, New York, pp. 1328.

Gower, J.C. 1971. A general coefficient of similarity and some of its properties. Biometrics 27: 857-871.

Jensen, K.B., Larson, S.R., Waldron, B.L. and Asay, K.H. 2006. Cytogenetic and molecular characterization of hybrids between 6x, 4x, and 2x ploidy levels in crested wheatgrass. Crop Sci. 46: 105-112.

Kalinowski, A., Klimko, M. and Wojciechowska, B. 2005. Pollen morphology and two-dimensional patterns of pollen coat and protoplast proteins in Aegilops kotchyi X Secale cereale amphiploids. Acta Biologica Cracoviensia series Botanica 47: 97-110.

Köhler, E. and Lange, E. 1979. A contribution to distinguishing cereal from wild grass pollen grains by LM and SEM. Grana 18: 133-140.

Kruse, J. 1980. Skulpturuntersuchungen an Pollen der Gattungen Triticum L. and Aegilops L. Kulturpflanze 28: 341-359.

Lewis, W., Vinay, H.P. and Zenger, V.E. (eds) 1983. Airborne and Allergenic Pollen of North America. The John Hopkins University Press, pp. 1-254. 
Liu, Q., Zhao, N.X. and Hao, G. 2004. Pollen morphology of the Chloriodoideae (Gramineae). Grana 43: $238-248$

Melderis, A. 1978. Taxonomic notes on the tribe Triticeae (Gramineae) with special reference to the genera Elymus L. s.1., and Agropyron Gaertner s.1. Bot. J. Linnean Soc. 76: 369-384.

Melderis, A. 1985. Agropyron (Gaertner). In: Davis, P.H. (ed.), Flora of Turkey and the East Aegean Islands. Vol. 9. University Press, Edinburgh, Scotland, pp. 204-206.

Melderis, A., Humpries, C.J., Tutin, T.G. and Heathcote, S.A. 1980. Tribe Triticeae Dumort. In: Tutin, T.G., Heywood, V.H., Burges, N.A., Moore, D.M., Valentine, D.H., Walters, S.M. and Webb, D.A. (eds), Flora Europaea. Vol. 5. Cambridge University Press, Cambridge, England, pp. 190-200.

Moore, P.D. and Webb, J.A. (eds) 1978. An Illustrated Guide to Pollen Analysis. Hodder and Stoughton, London, pp. 1-133.

Moore, P.D., Webb, J.A. and Collinson, M.E. 1991. Pollen Analysis. $2^{\text {nd }}$ Edition, Blackwell Scientific Publications, Osney Mead, Oxford, pp. 62-101.

Nevski, S.A. 1934. Tribe XIV. Hordeae Benth. In: Komorov, V.L. (ed.), Flora of the U.S.S.R. The Botanical Institute of the Academy of Sciences of the USSR, Leningrad, USSR, pp. 590-722.

Panajiotidis, S., Athanasiadis, N., Symenonidis, L. and Karataglis, S. 2000. Pollen morphology in relation to the taxonomy and phylogeny of some native Greek Aegilops species. Grana 39: 126-132.

Pehlivan, S., Bayrak, F. and Ozler, H. 2004. Comparison of pollen morphology and total proteins in some species of Poaceae from Turkey. Bangladesh J. Bot. 33: 109-114.

Perveen, A. 2000. Pollen characters and their evolutionary significance with special reference to the Flora of Karachi. Turk. J. Biol. 24: 365-378.

Perveen, A. 2006. A contribution of the pollen morphology of family Gramineae. World Applied Sciences Journal 2: 60-65.

Salgado-Labouriau, M.L. and Rinaldi, M. 1990. Palynology of Gramineae of the Venezuelan Mountains. Grana 29: 119-128.

Smith, E.G. 2000. Sampling and identifying allergenic pollens and molds. Blewstone Press, San Antonio, pp. 97-105.

Sneath, P.H.A. and Sokal, R.R. 1973. Numerical Taxonomy. Freeman, San Franciscoi, pp.1-513.

SPSS 1999. SPSS Base 10.0 for Windows User's Guide. SPSS Inc., Chicago.

Tzelev, N.N. 1976. Poaceae URSS. Tribe 3. Triticeae Dum. Genus 17. Agropyron, pp. 143-150. USSR Academy of Science Press, Leningrad.

Wodehouse, R.P. 1935. Pollen Grains. Hafner, New York, pp. 1-435. 